\title{
The effect of NP fertilization on European blueberry (Vaccinium myrtillus L.) development on cultivated land in mid-Norway
}

\author{
R. Nestby ${ }^{\mathrm{a}, *}$, T. Krogstad ${ }^{\mathrm{b}}$, E. Joner ${ }^{\mathrm{a}}$ and M. Vohník ${ }^{\mathrm{c}, \mathrm{d}}$ \\ ${ }^{\mathrm{a}}$ Norwegian Institute for Agricultural and Environmental Research (Bioforsk), Ås, Norway \\ ${ }^{\mathrm{b}}$ University of Life Sciences, Department of Environmental Sciences, Ås, Norway \\ ${ }^{\mathrm{c}}$ Department of Mycorrhizal Symbioses, Institute of Botany ASCR, Průhonice, Czech Republic \\ ${ }^{\mathrm{d}}$ Department of Experimental Plant Biology, Faculty of Science, Charles University in Prague, Prague, \\ Czech Republic
}

Received 7 April 2014; accepted 12 May 2014

\begin{abstract}
.
BACKGROUND: European blueberry (Vaccinium myrtillus L.; EB) is one of the most common shrubs in Nordic forests. It has been exploited through centuries by man and is considered a valuable food. However, it has not been domesticated and all EB fruit is harvested from forest fields. The investigations reported here were undertaken to examine the possibility of EB domestication. OBJECTIVE: With the aid of knowledge achieved through examinations of EB in natural forests and in cultivated fields of lowbush blueberry, the following trials were started to examine if EB could be grown on rich farmland by adaption of fertilization and addition of natural peat as mulch; and by planting EB mats from a forest field and EB seedlings in a strip of top soil (O-layer) from the same field, with the aim to introduce ericoid mycorrhizal (ErM) fungi.

METHOD: The experiments were performed as two field trials (A and B) on agricultural land. Trial A was a block design with four replications, examining the effect on plant growth of nine randomly broadcasted fertilization levels combining nitrogen and phosphorus on fresh planted EB seedlings. In addition, two out of four blocks were randomly mulched with natural peat. Trial B was a split-plot design with three blocks. Each block consisted of two large plots and each large plot contained two small plots. Two fertilization levels were randomly broadcasted in large plots, and two plant types [small plug seedlings propagated in sparsely fertilized peat; and mats of $(30 \times 20) \mathrm{cm}^{2}$ from a nearby forest field existing of O-layer and some of the E-layer (wash out soil layer)] were randomly planted in small plots. Seedling plants of trial B (similar plants as in Trial A) were planted in shallow furrows filled with forest soil. Fertilization were NOP0 (control; no fertilizer), and N1P1 (fertilized similar to a medium treatment of trial A). The seedling plants were in a juvenile phase in the year of planting, but the first fruits were observed in the third field year. This indicate that the plants had entered the generative phase.

RESULTS: In trial A fertilization increased spatial growth of EB plants and fruit number. However, $\mathrm{P}$ alone did not have any significant effect since the level in the soil was high already before establishing the experimental field. Fertilizing with $\mathrm{N}$ alone was most effective in terms of spatial growth and fruit number. However, when $\mathrm{P}$ fertilizer was applied together with $\mathrm{N}$ fertilizer, plant growth and fruit number increased more than when $\mathrm{N}$ was applied alone. Fertilization also increased levels of $\mathrm{P}$ and $\mathrm{S}$ in the soil. Top-dressing had positive effect on growth in the non-fertilized plots. Fertilization of top-dressed plots resulted in poorer plant growth except for $\mathrm{N}$ alone and strongest combined fertilization, and there was no clear effect on fruit number. In plots that were not fertilized top-dressing increased total amount of $\mathrm{C}, \mathrm{N}, \mathrm{Ca}$ and $\mathrm{Mg}$. In trial B mycorrhiza was present in all plots and probably influenced the uptake of nutrients by EB. It is of interest that some of the observed ericoid mycorrhiza was apparently formed by basidiomycetous hyphae.
\end{abstract}

\footnotetext{
*Corresponding author: R. Nestby, Norwegian Institute for Agricultural and Environmental Research (Bioforsk), Ås, Norway. E-mail: rolf.nestby@bioforsk.no.
} 
CONCLUSIONS: EB grown on agricultural land, were juvenile seedlings in trial A, was strongly influenced by NP fertilization. Fertilization with $\mathrm{N}$ gave stronger growth than fertilization with $\mathrm{P}$; however, plants fertilized with $\mathrm{P}$ grew better than control. Also, fertilization had positive influence on fruit number, either fertilizing with $\mathrm{N}$ alone or in combination with $\mathrm{P}$. Top-dressing with natural peat had positive influence on spatial growth, but no clear effect on fruit number. In trial B ericoid mycorrhizal colonization was present in all treatments in both seedlings (juvenile phase) and established plants in mats (generative phase), and it probably influenced uptake of nutrients. It could be suggested that growing EB on cultivated land is possible, but preferably on a more acid soil than in these trials.

Keywords: Soil, nitrogen, phosphorous, mycorrhiza, plant type

\section{Introduction}

European blueberry (EB) ground vegetation is the most widespread vegetation type in Norwegian coniferous forest [5], covering nearly $35 \%$ of the productive forest area [11]. For proper growth and development, Vaccinium species demand relatively low soil $\mathrm{pH}$ and good drainage. Studies of natural vegetation suggest that the best EB yield could be obtained in a mature pine-dominated stand, which is not too dense as the amount of light which reaches the ground is important [7]. Fertile locations are more favorable than poor locations; some studies have shown that forests of medium fertility produce the largest EB yields in the boreal zone. It was also found that $\mathrm{N}$ and $\mathrm{P}$ fertilization over four years in forest fields of EB increased shoot growth, but had generally neutral or negative effect on fruit yield depending on the NP level [14]. EB have a shallow and weakly developed root system, but the biomass of rhizomes and roots may be of a similar volume as the above ground part. Older rhizomes usually occur at the boundary with the mineral soil, while younger rhizomes are more superficial with roots usually found in the upper part of the O-horizon of podzolic soils. The humus properties therefore, appear to be of a great importance for EB vegetation. However, roots from older rhizomes may be exceedingly tortuous, descending more than $45 \mathrm{~cm}$ into the mineral soil [3]. The low $\mathrm{pH}$ of the natural growth substrate causes low availability of nutrients for plants. However, $\mathrm{N}$ and $\mathrm{P}$ deficiency symptoms have not often been reported for Vaccinium species of natural vegetation even if they are high yielding. This is mainly due to the ericoid mycorrhizal (ErM) symbiosis between EB roots and ErM fungi. Ericoid mycorrhiza provides access to $\mathrm{N}$ and $\mathrm{P}$ sources that would be otherwise not available to plant roots alone; under natural conditions, the capacity to provide nutrients and protect host plants against metal toxicity and other abiotic stresses is indispensable for proper growth of most Ericaceae $[12,16]$. ErM fungal colonization is limited to rhizodermal cells of the delicate hair roots which are characteristic for Ericaceae.

However, growth-limiting conditions are usually not prevalent on cultivated land where $\mathrm{pH}$ is typically higher than 5.5 and therefore, must be lowered to improve growth conditions for successful EB cultivation. This can be achieved by several means but application of sulfur and acid-forming fertilizers are the most common [1,24]. Adding of organic material as mulch is also frequently used, and may improve growth and yield [2, 13, 23]. The effect of fertilizers containing one element or several elements combined, have frequently been examined in lowbush blueberry (Vaccinium angustifolium Aiton) and show that both foliar and soil application of fertilizer may be beneficial, both alone and combined. Positive effects were obtained by fertilization with N, P, Ca, B and Zn (diammoniumphosphate seems to be a particularly suitable source of $\mathrm{N}$ and $\mathrm{P}$ ), but application of potassium (K) is also reported to have a negative effect $[8,15,22]$. Studies of EB in Norway spruce forests showed that the amount of remobilized $\mathrm{N}$ depended on the level of $\mathrm{N}$ reserves, and on number of initial buds that produced shoots. Nitrogen remobilization and the growth response to $\mathrm{N}$ supply were closely linked to the pattern of bud activation [6]. In areas with high $\mathrm{N}$ deposition, EB was less frequent, less abundant and more susceptible to the leaf pathogen Valdensia heterodoxa than in areas with lower levels of $\mathrm{N}$ deposition [25]. It is plausible that $\mathrm{EB}$ reacts to $\mathrm{pH}$ and fertilization similarly as the lowbush blueberry.

Despite that blueberry plantations typically obtain high nutrient inputs in a form of mineral fertilizers which attenuate the positive effects of mycorrhizal symbioses on host nutrition, cultivated Vaccinium species nevertheless commonly possess ErM symbiosis. The levels, however, vary with plantation age, soil nutrient content and Vaccinium cultivars $[17,19,20]$. Several authors attempted artificial inoculation of blueberries with selected strains of ericoid mycorrhizal fungi [18, 21], but this did not always lead to an increased growth and/or fruit production. Positive results 
may be obtained when mineral fertilizers are substituted by organic matter input [26], but even then the effect of soil saprotrophic fungi decomposing the introduced organic matter on blueberry growth and fruiting may be higher than that of true ErM fungi [28].

With the aid of knowledge achieved through examinations in natural forest with EB and cultivated fields of lowbush blueberry, the following trials were started to examine if EB could be grown on rich farmland by adaption of fertilization, addition of natural peat as mulch and by introducing EB mats or forest soil to possibly introduce EmR fungi.

\section{Materials and methods}

\subsection{Soil and plant material}

The experiments were undertaken on farmland in Central Norway, at Bioforsk Grassland and Landscape division (N63 ${ }^{\circ} 47^{\prime}$; E10 $92^{\prime}$; $38 \mathrm{~m}$ above sea level). The soil was a well- drained silt loam with high amount of organic material in the plough layer $(0-23 \mathrm{~cm})$ with $\mathrm{pH}$ 5.9. The mineral content was 26,53 and $21 \%$ of sand, silt and clay, respectively. Before the start of the experiments it was necessary to lower $\mathrm{pH}$, and a $10 \mathrm{~cm}$ layer of natural peat was rotated into the soil. This lowered $\mathrm{pH}$ to 4.8 which increased to 5.3 during the course of the experiments (2008-2011). $\mathrm{pH}$ was measured in a deionized water to soil ratio (v/v) of 2.5 [9]. Total $\mathrm{C}$ and $\mathrm{N}$ were analyzed by a high temperature resistance furnace method by using the instrument LECO CHN-1000. Soil mineral nutrients were analyzed before peat was added using the Al-method, which is an extraction using ammonium lactate solution with a pH of 3,75 (P-AL 158, K-AL 62, Mg-AL 141 and Ca-AL $2910 \mathrm{mg} \mathrm{kg}^{-1}$ of soil) [9]. In the end of the experiments in September 2011 the soil was sampled in the same way as in 2008, but in addition the AL extracts were analyzed for sulfur. The values for the mineral nutrients were, in average of all plots, P-AL 223, K-AL 65, Mg-AL 282 and Ca-AL 3092. All nutrients were analyzed by use of ICP-OES. EB plants were either seedlings originating from seeds of a nearby natural population, or clones (intact mats of $30 \times 20 \mathrm{~cm}$ ) from a nearby location of similar altitude. The mats consisted of rhizomes, organic material and some mineral soil from the wash out layer. The seeds were sawn in March 2008 in natural peat in trays and pricked off into pots (diam. $8 \mathrm{~cm}$ ) in May 2008. They were planted on beds in agricultural soil in July 2008 and had normally one shoot of approx. $5 \mathrm{~cm}$ in length. The clones were planted at the same date.

\subsection{Experimental designs}

\subsubsection{Trial A-fertilization}

This trial was randomized block with four replications. The plots were on $20 \mathrm{~cm}$ high and $65 \mathrm{~cm}$ wide ridges with $120 \mathrm{~cm}$ between the middles of ridges, and each plot was planted with seedlings randomly selected from a large population. There were two plant rows $20 \mathrm{~cm}$ apart on the ridge and seedlings in one row were planted alternate to seedlings in the neighbor row with a plant space of $11.5 \mathrm{~cm}$. Each plot included 25 plants one the ridge covering $(150 \times 65) \mathrm{cm}^{2}$. Treatments were fertilization and mulching. Mulching was undertaken each spring by adding a $2 \mathrm{~cm}$ layer of natural peat on the beds (top-dressing) in two out of four replications randomly selected, leaving the two other replications as control. Nine fertilization levels were randomly broadcasted by hand in plots within each replication (Table 1). Fertilizers used were ammonium sulfate (21-0-0) $\left(\mathrm{NH}_{4} \mathrm{SO}_{4}, \mathrm{SSAB}\right.$ Merox AB, Sweden) and Yara OPTI $\mathrm{P}^{\mathrm{TM}}$ (0-8-0) (Yara Norge AS, Norway). They were used because of their potential to reduce the $\mathrm{pH}$ level, and they were combined to achieve combinations of $\mathrm{N}$ and $\mathrm{P}$ according to the plan. The fertilizer was added with half the amount given in Table 1 first of June and similarly first of August each year of the experimental period. However, in 2008 the season was much shorter and half amount was added in August three weeks after planting (11 July).

Plant growth was measured in 2009, 2010 and 2011. Growth of each plant in the plot was obtained by calculating spatial occupation of plant crown by measuring plant width, length and height in $\mathrm{cm}$ of one decimal accuracy.

Soil samples for estimations of $\mathrm{pH}$ and mineral nutrients were sampled when the trial terminated in September 2011. Samples were taken by a hand bore $20 \mathrm{~cm}$ deep with 10 samples per plot. The soil samples were air dried before they were transported to 'Norwegian University of Life Sciences' (NMBU), Department for environmental 
Table 1

Fertilization treatment (2008-2011) of trial A. Annual application of full growing seasons at Stjørdal, Norway

\begin{tabular}{lcc}
\hline Treatment & \multicolumn{1}{c}{ Fertilizer in kg-ha $^{-1}$} \\
\cline { 2 - 3 } & Nitrogen (N) & 0 \\
N0P0 & 0 & 0 \\
N1P0 & 17.5 & 0 \\
N2P0 & 35.0 & 15.0 \\
N0P1 & 0 & 30.0 \\
N0P2 & 0 & 15.0 \\
N1P1 & 17.5 & 30.0 \\
N1P2 & 17.5 & 15.0 \\
N2P1 & 35.0 & 30.0 \\
N2P2 & 35.0 &
\end{tabular}

Sciences, for analyses. The field was covered with AgroCover (Rovero, the Netherlands) to protect the small plants in the two first winters against freezing. It was irrigated in the growing season when necessary, using drip-irrigation. Weeds were periodically removed by hand. However, in spring and autumn of the last two experimental years, half dose of Gallery (DOWTM, USA) was used to prevent weed germination using recommendations of strawberry. It was not sprayed against diseases or pests.

\subsubsection{Trial $B-$ mycorrhiza}

The experiment was set up in the same field as Experiment A and the cultivation practice was identical. The experimental design was split-plot with three replications. The treatments were I) fertilization (NOP0 $=0 \mathrm{~kg} \mathrm{~N}$ and $0 \mathrm{~kg} \mathrm{Pha}^{-1}$, and N1P1 $=35 \mathrm{~kg} \mathrm{~N}$ and $30 \mathrm{~kg} \mathrm{Pha}^{-1}$ ) broadcasted randomly on large plots, and II) plant type (seedlings planted in a $5 \mathrm{~cm}$ wide and deep strip of forest soil along each row with 25 plants per plot, and mats, three per plot; randomly distributed on small plots).

For estimation of fungal root colonization, EB rhizomes with roots were dug up when the trial was terminated in September 2011, and root samples of ca. 0.2-0.5 g (FW) from five plants per plot were washed free of the adhering soil, mixed to make a compound sample, cleared with $10 \% \mathrm{KOH} 20$ minutes at $121^{\circ} \mathrm{C}$, acidified 1 minute in $3 \% \mathrm{HCl}$ and stained with trypan blue $(0.05 \%$ solution in lactoglycerol) overnight at room temperature. The stained EB hair roots were examined for presence and extent of fungal colonization (ericoid mycorrhiza, dark septate endophytes; [27]); using an Olympus BX60 microscope equipped with DIC. Root samples were screened at $400 \times$ and $1000 \times$ magnification and the fungal colonization was estimated after screening 50 fields of view per each compound sample.

Spatial growth was calculated as cubic $\mathrm{cm}$ after measuring length, width and height of the crown of single plants or mats. To make the comparison between the two plant types comparable the spatial occupation of the plants were calculated to liters per square meter.

\section{Results and discussion}

\subsection{Trial A}

\subsubsection{Effects of fertilization on spatial plant growth and fruit number}

Fertilization influenced plant growth strongly. Control plants (NOP0) grew lesser as a sum of years (2011) than any other treatment in plots not top-dressed; when top-dressed control and NOP2 grew lesser than all other top-dressed treatments, demonstrating that NP fertilization at most levels used in this trial improved spatial growth (Table 2). This is visualized in Fig. 1 where control plants at the lower right have poorer growth than the other three treatments shown. 

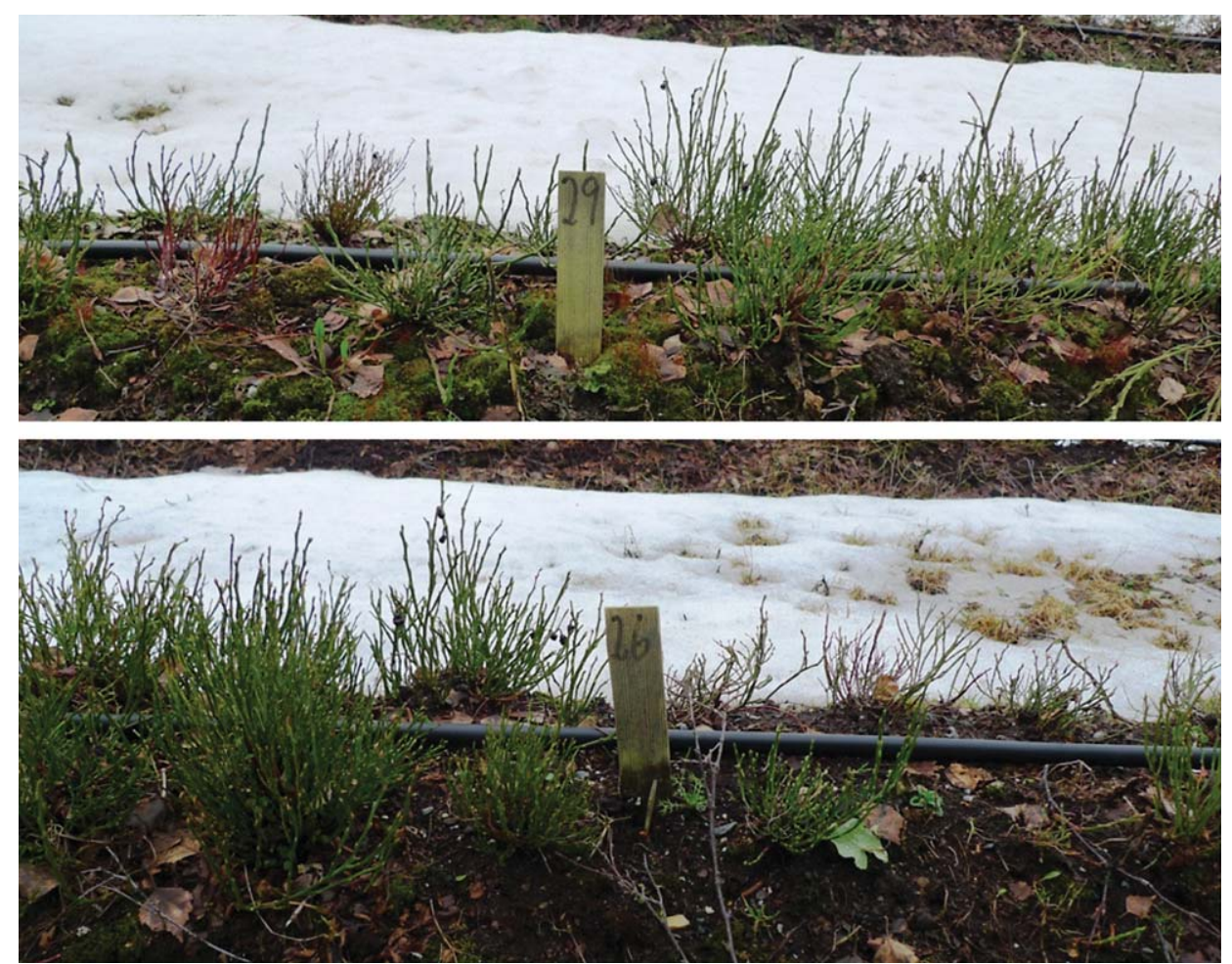

Fig. 1. Effect of fertilization on size of EB seedling-plants after three growth seasons. The row behind is N0P1 to the left and N2P1 to the right, the front row is N2P0 and N0P0 (control), respectively left and right. Photos are taken 15 March 2012 in Stjørdal, Norway. Photo: Rolf Nestby

However, the experiments revealed different growth reactions caused by N (nitrogen) and P (phosphorus). In 2009 sole P-fertilization (NOP1 and NOP2) gave similar or poorer shoot growth than control, and top-dressing did not alter that. The rhizome and root growth was not examined. The poor or none effect of $\mathrm{P}$ is not surprising considering the high level (158 mg P kg-1) in soil previous to planting. A level higher than $150 \mathrm{mg} \mathrm{P} \mathrm{kg}^{-1}$ is classified as very high in cultivated soil [9]. At termination of the trial in the autumn of 2011 the average of all plots was $223 \mathrm{mg} \mathrm{P} \mathrm{kg}^{-1}$. In spite of the high P level in soil, plants in 2010 fertilized with only P had better growth than control. The final year, which is the result of three years of full fertilization and one year of half level of fertilizer, demonstrate that when no top-dressing was added, fertilization with $\mathrm{P}$ alone increased the growth strongly compared with control, especially at lowest P-level.

Top-dressing changed this picture and initiated growth of control plants at termination of the trial in between the effects of the two P levels, and obviously improved the long term growing conditions by more than doubling the growth compared to no top-dressing of control (Table 2). It could be suggested that the soil top layer, which became thicker throughout the years, became a better growth medium for EB. This is in agreement with general findings in Vaccinium showing improvement of plant development and yield following mulching with organic material [2, 4 , 11, 23]. However, combining NP fertilization or using $P$ fertilizer alone together with top-dressing, did not increase growth or reduced it (except for N2P2) compared with no top-dressing. $\mathrm{N}$ alone was in contradiction favorable combined with top-dressing by improving growth compared to no top-dressing. This indicate that plants did not benefit from combining $\mathrm{P}$ alone and top-dressing, in spite of increase in soil $\mathrm{P}$ at termination of the trial, suggesting that $\mathrm{P}$ availability was higher than optimum (Fig. $2 ; P=0.05$ ).

Effect of $\mathrm{N}$ on plant growth was relatively stronger than of $\mathrm{P}$, and highest $\mathrm{N}$-level (N2P0) initiated stronger growth than the lowest level, and stronger growth than any level of $\mathrm{P}$ alone in any year, except for N0P1 in 2011 compared with N1P0 without top-dressing (Table 2). 
Table 2

Effect in three years on spatial growth $\left(\mathrm{cm}^{3}\right)$ of NP fertilization and top-dressing (Td) of EB (V. myrtillus L.) growing in mineral soil on cultivated land in Stjørdal, Norway

\begin{tabular}{|c|c|c|c|c|c|c|}
\hline \multirow[t]{2}{*}{ NP } & \multicolumn{2}{|c|}{2009} & \multicolumn{2}{|c|}{2010} & \multicolumn{2}{|c|}{2011} \\
\hline & $\mathrm{Td}$ & No Td & $\mathrm{Td}$ & No Td & $\mathrm{Td}$ & No Td \\
\hline NOP0 & 240.6 & 243.7 & 887.8 & 805.1 & 4263.4 & 2385.3 \\
\hline N1P0 & 395.8 & 525.5 & 1801.9 & 1531.3 & 4975.9 & 3748.9 \\
\hline $\mathrm{N} 2 \mathrm{P} 0$ & 870.2 & 981.2 & 3488.7 & 2225.6 & 7435.7 & 5056.9 \\
\hline NOP1 & 159.6 & 212.0 & 1082.5 & 1394.6 & 4864.8 & 4556.5 \\
\hline NOP2 & 223.1 & 282.8 & 1209.7 & 1810.4 & 3850.5 & 3538.8 \\
\hline N1P1 & 431.3 & 679.5 & 2358.0 & 2831.2 & 6779.1 & 8044.9 \\
\hline $\mathrm{N} 1 \mathrm{P} 2$ & 505.1 & 958.9 & 2577.6 & 3014.2 & 6535.5 & 7510.9 \\
\hline $\mathrm{N} 2 \mathrm{P} 1$ & 381.0 & 995.8 & 1862.5 & 3568.6 & 5217.6 & 7645.0 \\
\hline $\mathrm{N} 2 \mathrm{P} 2$ & 878.1 & 487.6 & 3719.2 & 1536.0 & 8616.6 & 4191.5 \\
\hline Mean & 453.9 & 596.3 & 2109.8 & 2079.7 & 5837.7 & 5186.5 \\
\hline $\mathrm{Se}_{\mathrm{NP}}$ & $27.9^{* * *}$ & $27.9^{* * *}$ & $125.2^{* * *}$ & $125.2^{\text {*** }}$ & $278.0^{* * *}$ & $278.0^{* * *}$ \\
\hline $\mathrm{Se}_{\mathrm{Td}}$ & & $83.6^{* * *}$ & & $375.5^{\mathrm{ns}}$ & & $834.0^{\text {ns }}$ \\
\hline
\end{tabular}

$\mathrm{Ns}, *, * *, * * *$ are not significant, significant on the $5 \%$ level, $1 \%$ level and $0.1 \%$ level, respectively.

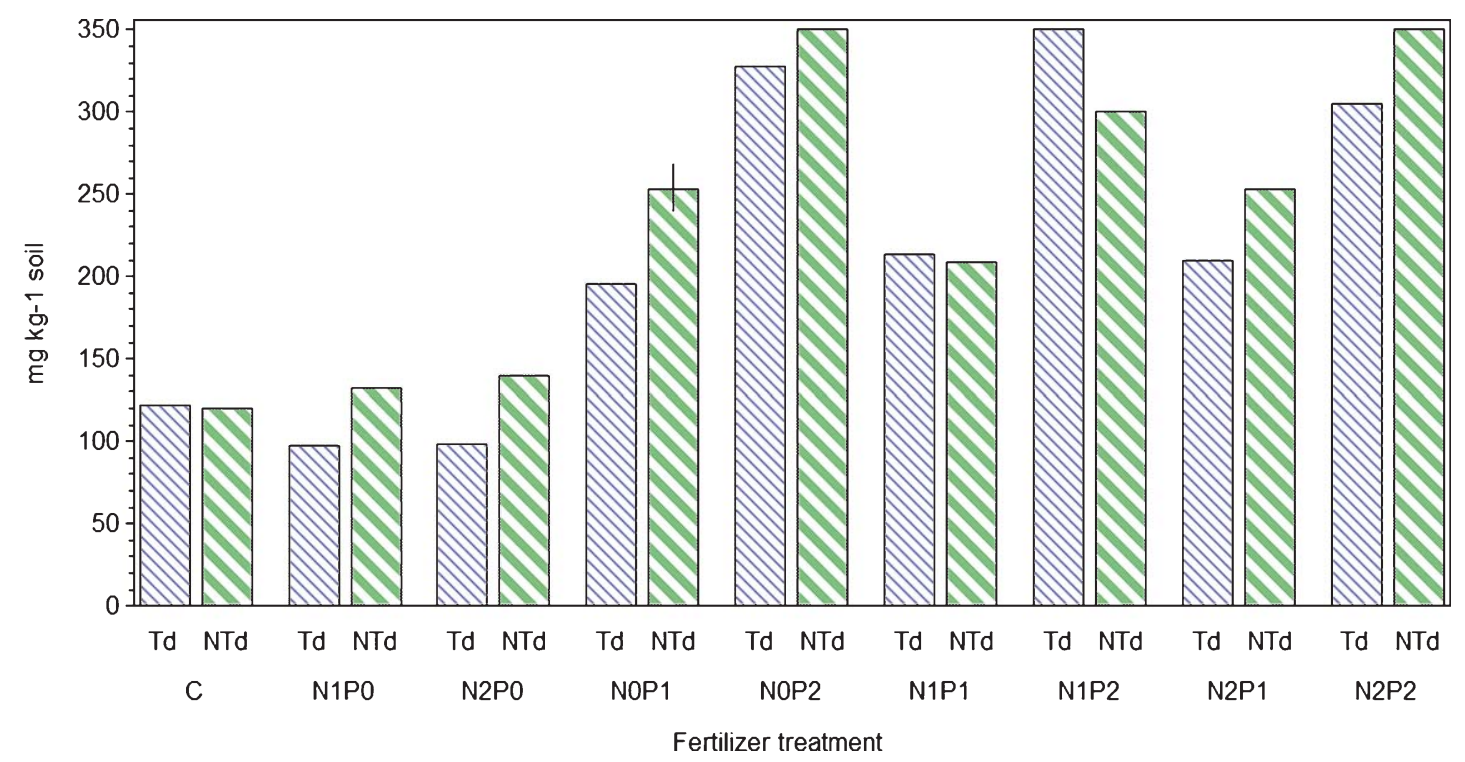

Fig. 2. Effect of NP fertilization and top-dressing $(\mathrm{Td}=$ dressing, NTd=no dressing) in EB grown in mineral soil on soil P-level in Stjørdal, Norway in 2011. Bar is standard error valid for all comparisons.

Treatments without top-dressing of combined $\mathrm{N}$ and $\mathrm{P}$ fertilizers gave better growth than single application of fertilizers and control. Except for the strongest fertilization (N2P2) that resulted in growth on level with or lower than any single application of fertilizer, which was a result of poor growth in each of the experimental years. There was one exception in 2009 when N2P0 had similar growth as N1P2 and N2P1 (Table 2). However, plants grown in top-dressed soil behaved different and grew less than plants on not top-dressed soil, except for control, $\mathrm{N}$ alone and $\mathrm{N} 2 \mathrm{P} 2$ which resulted in the strongest growth of the trial. 

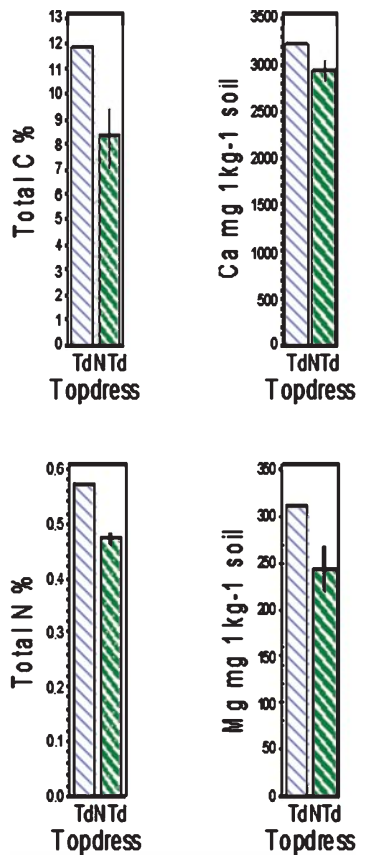

Fig. 3. Effect of top-dressing on total -C, -N, -Ca and -Mg in control plots of cultivated land in Stjørdal, Norway 2011.

Table 3

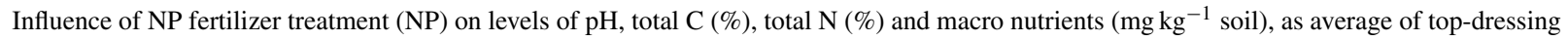
treatments in soil of an EB field on agricultural land, after final termination of experiments September 2011, in Stjørdal, Norway

\begin{tabular}{|c|c|c|c|c|c|c|}
\hline NP & $\mathrm{pH}$ & $\mathrm{C}$ & $\mathrm{N}$ & $\mathrm{Ca}$ & $\mathrm{K}$ & $\mathrm{Mg}$ \\
\hline NOPO & 5.76 & 9.9 & 0.52 & 3119 & 57.3 & 322 \\
\hline N1P0 & 5.39 & 11.2 & 0.57 & 2925 & 62.7 & 300 \\
\hline $\mathrm{N} 2 \mathrm{P} 0$ & 5.21 & 10.7 & 0.55 & 2718 & 61.5 & 254 \\
\hline NOP1 & 5.49 & 10.6 & 0.55 & 3153 & 60.9 & 316 \\
\hline NOP2 & 5.47 & 9.1 & 0.47 & 3366 & 68.4 & 284 \\
\hline N1P1 & 5.33 & 10.4 & 0.53 & 3309 & 65.4 & 288 \\
\hline $\mathrm{N} 1 \mathrm{P} 2$ & 5.22 & 10.7 & 0.54 & 3373 & 59.7 & 287 \\
\hline $\mathrm{N} 2 \mathrm{P} 1$ & 5.00 & 9.9 & 0.53 & 2739 & 66.4 & 231 \\
\hline $\mathrm{N} 2 \mathrm{P} 2$ & 4.98 & 8.4 & 0.46 & 3135 & 71.6 & 204 \\
\hline Mean & 5.32 & 10.1 & 0.53 & 3137 & 63.8 & 223 \\
\hline $\mathrm{Se}$ & $0.10^{* * *}$ & $3.1^{\mathrm{ns}}$ & $0.07^{\mathrm{ns}}$ & $183^{\mathrm{ns}}$ & $4.4^{\mathrm{ns}}$ & $47^{\mathrm{ns}}$ \\
\hline
\end{tabular}

$\mathrm{Ns}, *, * *, * * *$ are not significant, significant on $5 \%, 1 \%$ and $0.1 \%$ levels, respectively.

\subsubsection{Effects of fertilization on soil parameters}

Soil analyses indicated that level of soil $\mathrm{P}$ increased as a result of $\mathrm{P}$ - fertilization, and that top-dressing reduced the level except for $\mathrm{P}$ combined with the lowest $\mathrm{N}$-level, indicating significant interaction between $\mathrm{N}$ and $\mathrm{P}$ level and top-dressing on soil P (Fig. 2).

Top-dressing had influence of levels of total carbon $(\mathrm{C})$, total nitrogen $(\mathrm{N})$, calcium $(\mathrm{Ca})$ and magnesium $(\mathrm{Mn})$ (Fig. 3) of control treatment. In all cases levels were higher in top-dressed soils than without top-dressing. There were no significant effects on levels of $\mathrm{C}, \mathrm{N}, \mathrm{Ca}, \mathrm{K}$ and $\mathrm{Mg}$ in soil at termination of the trial as a result of fertilization (Table 3). 


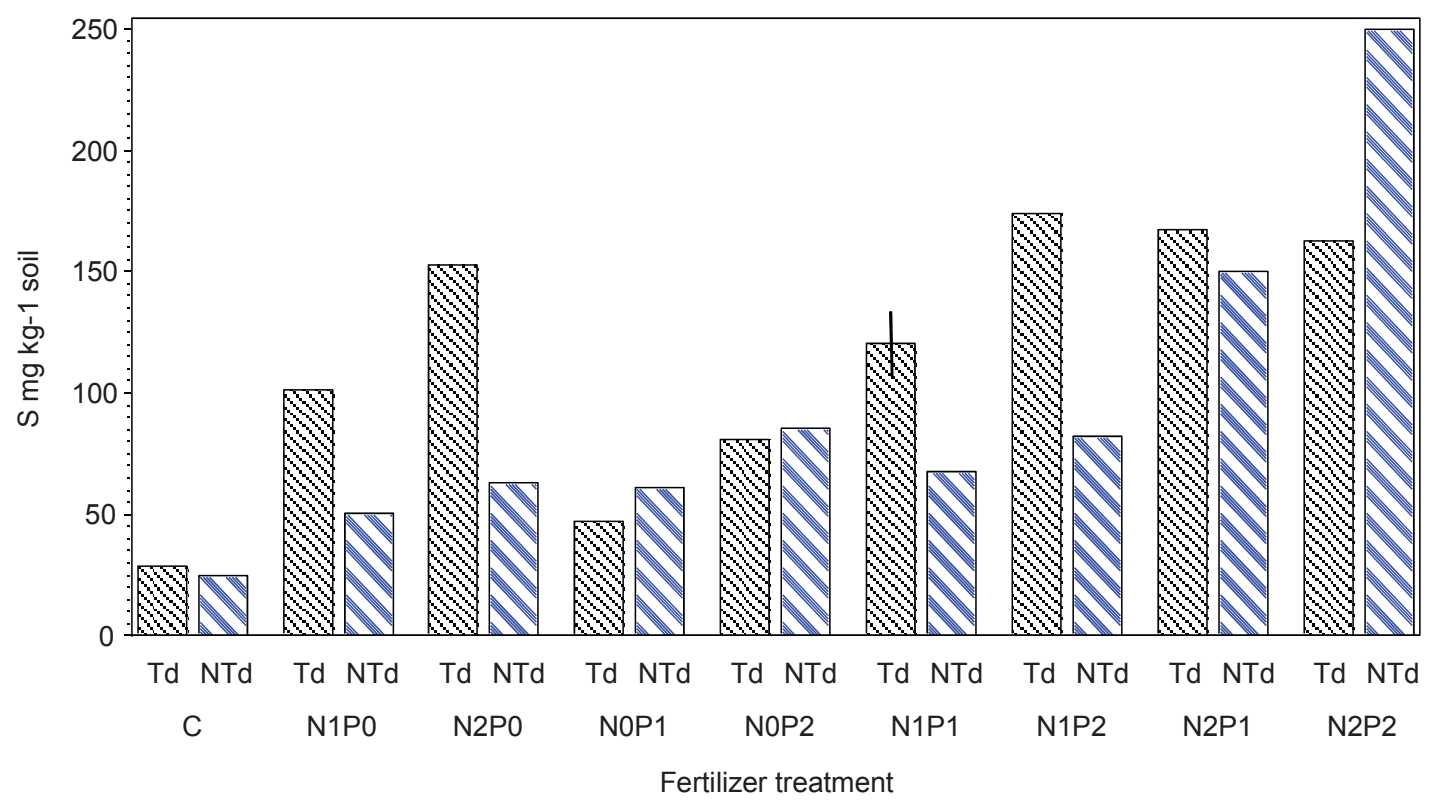

Fig. 4. Effect of NP-fertilization and top-dressing $(\mathrm{Td}=$ dressing, NTd=no dressing) in EB on cultivated land, on levels of soil-sulfur (S) at Stjørdal, Norway in 2011. The bar is a valid standard error for all comparisons.

Fertilization reduced $\mathrm{pH}$ level strongly (Table 3) and $\mathrm{pH}$ was negatively correlated with soil S (sulfur), which increased with fertilization but not with top-dressing alone (Fig. 4, $p=<0.0001$ ). This is in agreement with findings that suggest the use of $\mathrm{S}$ and acid-forming fertilizers to lower $\mathrm{pH}[1,24]$.

\subsubsection{Effects of fertilization on fruit number}

The plants were planted as first year seedlings and they developed no fruits in the planting year and the year after because they were in the juvenile phase. However, in 2010 at least some of the plants had entered the generative phase and developed fruits and even more in 2011. However, berries were foraged by birds in 2011 before we were able to count their amount. Fertilization had influence on fruit number in 2010 but there was no clear effect of top-dressing (Table 4). Control and the two treatments using $\mathrm{P}$ alone gave fewer fruits than the other treatments. Combining $\mathrm{N}$ and $\mathrm{P}$ generally resulted in the highest numbers of fruits. However, N2P2 without top-dressing resulted in no more fruits than $\mathrm{N}$ alone.

\subsection{Trial $B$}

\subsubsection{Presence of mycorrhiza}

Spatial growth of both seedlings and mats increased as an average of three years of fertilization. However, differences within a single year were generally not significant except for the mat culture in 2009 (Table 5). There were no interactions between year and fertilization or between plant type and fertilization.

Fertilization had influence on plant survival and more plants in the seedling culture had died at the end of the last experimental year as a result of fertilization. The mat culture was more robust and no plants died (Table 6).

All screened hair roots contained at least some fungal colonization (Table 7). In the screened hair roots we detected ericoid mycorrhiza, dark septate endophytic (DSE) association and the recently described basidiomycetous sheated ericoid mycorrhiza [28]. These types were often present together in one root sample and ericoid mycorrhizal and DSE hyphae were often intermingled. 
Table 4

Effect of NP fertilization and top-dressing (Td) on fruit number per plant in EB (Vaccinium myrtillus L.), grown on cultivated land in Stjørdal, Norway in 2010

\begin{tabular}{lcc}
\hline NP & \multicolumn{1}{c}{ Fruit number } \\
\cline { 2 - 4 } & \multicolumn{1}{c}{ Td } & 0 \\
\hline N0P0 & 0.23 & 0.24 \\
N1P0 & 0.39 & 0.53 \\
N2P0 & 0.39 & 0 \\
N0P1 & 0.06 & 0.03 \\
N0P2 & 0.08 & 0.71 \\
N1P1 & 0.52 & 0.51 \\
N1P2 & 0.97 & 0.64 \\
N2P1 & 0.63 & 0.30 \\
N2P2 & 1.24 & 0.33 \\
Mean & 0.50 & $0.09^{* *}$ \\
Se & $0.09^{* *}$ & \\
Se & & $0.27^{\text {ns }}$ \\
\hline
\end{tabular}

$\mathrm{Ns}, *, * *, * * *$ are not significant, significant on $5 \%, 1 \%$ and $0.1 \%$ levels, respectively.

Table 5

Effect in three years on spatial growth in liter $\mathrm{m}^{-2}$ of fertilization and plant type of EB (V. myrtillus L.) in Stjørdal Norway

\begin{tabular}{|c|c|c|c|c|c|c|c|c|}
\hline \multirow[t]{2}{*}{ Fertilization N-P } & \multicolumn{2}{|c|}{2009} & \multicolumn{2}{|c|}{2010} & \multicolumn{2}{|c|}{2011} & \multicolumn{2}{|c|}{ Mean } \\
\hline & Seedling & Mat & Seedling & Mat & Seedling & Mat & Seedling & Mat \\
\hline NOP0 & 4.05 & 69.77 & 16.49 & 88.93 & 68.83 & 125.05 & 29.79 & 94.58 \\
\hline N1P1 & 9.94 & 95.33 & 40.52 & 115.42 & 102.81 & 150.72 & 51.09 & 120.49 \\
\hline Mean & 7.00 & 82.55 & 32.56 & 102.07 & 97.45 & 137.75 & 40.44 & 107.53 \\
\hline $\mathrm{Se}$ & $3.09^{\mathrm{ns}}$ & $3.93^{*}$ & $10.21^{\mathrm{ns}}$ & $14.35^{\mathrm{ns}}$ & $6.22^{\mathrm{ns}}$ & $24.98^{\mathrm{ns}}$ & $3.52 *$ & $5.66^{* *}$ \\
\hline
\end{tabular}

$\mathrm{Ns}, *, * *, * * *$ are not significant and significant on $5 \%, 1 \%$ and $0.1 \%$ levels, respectively.

Table 6

Effect of NP fertilization on percentage plant survival of seedlings and mats of EB (V. myrtillus L.) in 2011 on cultivated land in Stjørdal, Norway

\begin{tabular}{lcc}
\hline N-P & Seedling & Mat \\
\hline NOP0 & 87.96 & 100.00 \\
N1P1 & 74.07 & 100.00 \\
Mean & 81.02 & 100.00 \\
Se & $2.82^{* *}$ & $100.00^{\text {ns }}$ \\
\hline
\end{tabular}

$\mathrm{Ns}, *, * *, * * *$ are not significant and significant on $5 \%, 1 \%$ and $0.1 \%$ levels, respectively.

The examination revealed that ErM fungi had colonized all plots when the trial terminated in September 2011. Since no plots were without introduced forest soil we can't be certain that the observed mycorrhizal colonization was caused only by this introduction. However, the mat culture had 50 to $100 \%$ colonization at all plots but one, which was less than $50 \%$. The seedling plots had 50 to $75 \%$ colonization, while two plots had $50 \%$ or less. This indicates that the seedlings had a little less colonization than the mats, which would be reasonable since the mats were colonized with mycorrhiza. The seedlings had to be colonized by mycorrhiza present in the soil before planting or from the strip of forest soil on the bed in which the seedlings were planted. Anyway, mycorrhiza was present and 


\section{Table 7}

Percentage colonization (Col) of ericoid mycorrhiza (ErM), DSE and basidiomycet hyphae forming ErM (Bas) in hair roots of EB seedlings and mats on cultivated land influenced by NP fertilization in Stjørdal, Norway in 2011

\begin{tabular}{llccc}
\hline NP & Plant type & Col\% & ErM\% & DSE\% \\
\hline N0P0 & Seedling & $50-75$ & 67 & 33 \\
& Mat & $50-75$ & 75 & 0 \\
N1P1 & Seedling & $50-75$ & 50 & 25 \\
& Mat & $<50-100$ & 40 & 25 \\
\hline
\end{tabular}

would influence the uptake of nutrients. It is of interest that a part of the observed ErM colonization was formed by basidiomycetous hyphae and resembled the recently described sheathed ericoid mycorrhiza [28].

\section{Conclusions}

In the trial A the seedlings of EB grown on agricultural land were strongly influenced by NP fertilization. Fertilization with $\mathrm{N}$ gave stronger growth than fertilization with $\mathrm{P}$, which is not surprising considering the high level of $\mathrm{P}$ in soil. In spite of the high P level in soil, plants fertilized with $\mathrm{P}$ grew better than control when the soil was not top-dressed. When the seedlings entered the generative phase in the third year after planting (2010), fruit number was examined and it was clear that fertilization had positive influence on fruit number, either fertilizing with $\mathrm{N}$ alone or in combination with $P$.

Top-dressing with natural peat had positive influence on spatial growth and interacted with fertilization so that strong effect on spatial growth fertilizing with $\mathrm{P}$ without top-dressing was strongly reduced when top-dressed. Top-dressing had no clear effect on fruit number.

In the trial B mycorrhiza was present in all treatments and would influence the uptake of nutrients. Fertilization increased spatial growth of both seedlings (juvenile phase the two first years thereafter generative) and mats (generative phase from the start), but there were no interactions between plant type and year or fertilization.

It could be suggested that establishing EB on cultivated land is possible since the field was managed with good result in four years on a soil that was not ideal for EB. However, lowering $\mathrm{pH}$ by rotating a thick layer of natural peat into the soil was effective, and the acid fertilizers used in the trials managed to stabilize the $\mathrm{pH}$ at a low level. Domestication would probably be easier and more cost effective using a more suitable soil.

\section{Acknowledgments}

This study was financed by the Norwegian Research Council (Project \#: 184797/I10). It was also supported by the long-term research projects of the Institute of Botany ASCR (RVO 67985939) and Charles University in Prague (SVV 265203/2012). The authors want to thank Sigrid Alstad at Bioforsk, Norway, for field and registration management in the project period.

\section{References}

[1] Albert T, Raspe O, Jacquemart AL. Clonal diversity and genetic structure in Vaccinium myrtillus populations from different habitats. Belgian Journal of Botany. 2004;137:155-62.

[2] Clarck JR, Moore JN. Southern blueberry response to mulch. Hort Technology. 1991; 52-54.

[3] Flower-Ellis JGK. Age structure and dynamics in stands of European blueberry (Vaccinium myrtillus L.). Ph.D. Dissertation. Res Notes 9. Royal College For. Stockholm. 1971; 108 pp.

[4] Gustavsson BA. Effects of mulching on fruit yield, accumulated plant growth and fungal attack in cultivated lingonberry, cv. Sanna, Vaccinium vitis-idaea L. Gartenbauwissenschaft. 1999;64:65-9. 
[5] Fremstad E. Norwegian vegetation types. NINA temahefte. 1997;12:1-279.

[6] Grelet GA, Alexander IJ, Millard P, Proe FM. Does morphology or the size of the internal nitrogen store determine how Vaccinium spp. respond to spring nitrogen supply? Functional Ecology. 2003;17:690-9.

[7] Ihalainen M, Ahlo J, Kolehmainen O, Pukkula T. Expert models for bilberry and cowberry yields in Finish forests. Forest Ecology and Management. 2002;157:15-22.

[8] Jeliazkova EA, Percival DC. N and P fertilizers, some growth variables, and mycorrhiza in wild blueberry /Vaccinium angustifolium). In Eds. P. Hicklenton and J. Maas, Acta Hort. 2003;626:297-304.

[9] Krogstad T. Metoder for jordanalyser. Institutt for jordfag, Rapport nr. 6/92. 1992; 32 pp. (In Norwegian)

[10] Kutschera L, Lichtenegger E. Wurtzelatlas mitteleuropäischer Grünlandspflanzen, Part 1, Morphologie, Anatomie,Ökologie, Verbreitung, Sosiologi Wirtschaft. None part 1, 1992.

[11] Larsson JY, Kielland-Lund J, Søgnen SM. Barskogens vegetasjonstyper. Oslo, Norway: Landbruksforlaget, 1994.

[12] Myers MD, Leake JR. Phosphodiesters as mycorrhizal P sources. 2. Ericoid mycorrhiza and the utilization of nuclei as a phosphorous and nitrogen source by Vaccinium macrocarpon. New Phytologist. 1996;132:445-51.

[13] Nesmith DS. Survival and vigor of southern highbush blueberry genotypes with and without pine bark mulch. Small Fruits review 2. 2003; 81-6.

[14] Nestby R, Martinussen I, Krogstad T, Uleberg E. Effect of fertilization, tiller cutting and environment on plant growth and yield of European blueberry (Vaccinium myrtillus L.) in Norwegian forest fields. Journal of Berry Research. 2014;4:79-95.

[15] Percival DC, Sanderson KR. Main and interactive effects of vegetative year applications of nitrogen, phosphorous and potassium fertilizer on the wild blueberry. Small Fruits Review 3. 2003; 105-21.

[16] Read DJ. The role of mycorrhiza in the nutrition of ericaceous plants with special reference to the genus Vaccinium L. Productions spontanees Colloque Colmar. 1980; 191-203.

[17] Scagel CF. Mycorrhizal status of sand-based cranberry (Vaccinium macrocarpon) bogs in southern Oregon. Small Fruits Review 2. 2003; 31-41.

[18] Scagel CF. Inoculation with ericoid mycorrhizal fungi alters fertilizer use of highbush blueberry cultivars. Hortscience. 2005;40:786-94.

[19] Scagel CF, Yang WQ. Cultural variation and mycorrhizal status of blueberry plants in NW Oregon commercial production fields. International Journal of Fruit Science. 2005;5:85-111.

[20] Scagel CF, Wagner A, Winiarski P. Frequency and intensity of root colonization by ericoid mycorrhizal fungi in nursery production of blueberry plants. Small Fruits Review 4. 2005a; 95-112.

[21] Scagel CF, Wagner A, Winiarski P. Inoculation with ericoid mycorrhizal fungi alters root colonization and growth in nursery production of blueberry plants from tissue culture and cuttings. Small Fruits Review 4. 2005b; 113-35.

[22] Smagula JM, Litten W, Loennecker K. Diammomium phosphate application date affects Vaccinium angustifolium Ait. Nutrient uptake and yield. Small Fruits Review 3. 2004; 87-94.

[23] Spiers JM. Establishment and early growth and yield of 'Gulfcoast' southern highbush blueberry. Hort Science. 1998;33:1138-40.

[24] Starast M, Karp K, Zimmer K, Tasa T. The effect of fertilizer on the growth of lowbush blueberry (Vaccinium angustifolium Ait.) in mineral soil. Transactions of the Estonian Agricultural University, Agronomy. 2001;212:155-60.

[25] Strengbom J, Walheim M, Nasholm T, Ericson L. Regional differences in the occurrence of understory species reflects nitrogen deposition in Swedish forests. Ambio. 2003;32:91-7.

[26] Vohník M, Albrechtová J, Vosátka M. The application of inoculate based on ericoid mycorrhizal, DSE and saprotrophic fungi in conventional, semi-conventional, semi-organic and organic cultivation of highbush blueberries. In: Feldmann F, Kapulnik Y, Baar J (Eds.): Mycorrhiza Works, ISBN 978-3-941261-01-3. 2008; 173-85. Deutsche Phytomedizinische Gesellschaft, Braunschweig, Germany.

[27] Vohník M, Albrechtová J. The co-occurrence and morphological continuum between ericoid mycorrhiza and dark septate endophytes in roots of six European Rhododendron species. Folia Geobotanica. 2011;46:373-86.

[28] Vohník M, Sadowsky JJ, Lukešová T, Albrechtová J, Vosátka M. Inoculation with wood decomposing basidiomycete, but not with root symbiotic ascomycetes, positively affects growth of highbush blueberry (Ericaceae) grown in a pine litter substrate. Plant and Soil. 2012a;355:341-52

[29] Vohník M, Sadowsky JJ, Kohout P, Lhotáková Z, Nestby R, Kolař;ík M. Novel root-fungus symbiosis in Ericaceae: Sheathed ericoid mycorrhiza formed by a hitherto undescribed basidiomycete with affinities to Trechisporales. PLoS ONE http://dx.plos.org/10.1371/journal.pone.0039524. 2012b.

[30] Wallenius TH. Yield variations of some common wild berries in Finland in 1956-1996. Ann Bot Fenn. 1999;36:299-314. 